\title{
A new solution to the "difficult problem" of the object of study of political economy
}

\author{
Jiguo Yang \\ Economics School, Xiamen University, Xiamen, China, and \\ Renshu Yuan \\ Guizhou Normal University, Guiyang, China
}

\begin{abstract}
Purpose - As there are different interpretations of the object of study in the preface to the first edition of Capital (Volume I) by Karl Marx, disagreements arise over the object of study on political economy, which becomes a "difficult problem." The purpose of the paper is to bring a new solution to the "difficult problem." Design/methodology/approach - Based on the analysis of the logic of the original text, the authors attempted to give a new interpretation of the "difficult problem" by analyzing the structure of Capital. The object of study of political economy is "the relations of production in the broad sense" of the capitalist mode of production.

Findings - It comprises relations of production in the narrow sense and exchange relations in the broad sense, and the latter can be divided into exchange relations in the narrow sense and distribution relations. The three of them correspond to Volume I, II and III of Capital, respectively. Consumption in "the four-section theory" is not studied by the political economy.

Originality/value - And the four-section theory is not a part of the theory of Marxist economics but a part of the classical economics criticized by Marx. Therefore, the object of study of socialist political economy with Chinese characteristics is "the relations of production in the broad sense" regarding the socialist mode of production with Chinese characteristics, which is different from the capitalist relations of production in the broad sense.
\end{abstract}

Keywords Socialist political economy with Chinese characteristics, Object of study, Difficult problem, Relations of production in the broad sense

Paper type Research paper

\section{Introduction}

Since Xi Jinping, president of the People's Republic of China, proposed the construction of "socialist political economy with Chinese characteristics," scholars have actively responded to the call by carrying out theoretical exploration and thus put forward considerable achievements. "Socialist political economy with Chinese characteristics" is a new theoretical system. The construction of a theoretical system usually requires four basic elements: object, method, purpose and content of study. Currently, the study of socialist political economy with Chinese characteristics mainly focuses on the purpose and content of the study with little emphasis on the method and the object of study. We have found only one article that takes socialist political economy with Chinese characteristics as the object of study (Wei, 2016) [1]. As to the method of studying socialist political economy with Chinese characteristics,

(C) Journal of Xiamen University(Arts \& Social Sciences). Published in China Political Economy. Published by Emerald Publishing Limited. This article is published under the Creative Commons Attribution (CCBY 4.0) licence. Anyone may reproduce, distribute, translate and create derivative works of this article (for both commercial and non-commercial purposes), subject to full attribution to the original publication and authors. The full terms of this licence may be seen at http://creativecommons.org/licences/by/4.0/legalcode. Originally published in Simplified Chinese in Journal of Xiamen University (Arts \& Social Sciences).

The article was published in Journal of Xiamen University (Arts and Social Sciences), Issue 4, 2018. 
CPE

4,2

Yang (2017) has written a monograph. The object of study on the traditional political economy remains a debatable problem. Therefore, scholars should clarify the object of study of political economy before defining the object of study on socialist political economy with Chinese characteristics. Therefore, the main task of this article is to explore the object of study of political economy from a new perspective, which based on the sample analysis of the structure of Capital, to discuss the object of study of socialist political economy with Chinese characteristics briefly.

The research on the object of study of political economy is divided into two stages: before reform and opening-up and after reform and opening-up. Also, a consensus was reached before reform and opening-up - i.e. the object of study of political economy is relations of production. Although some scholars disputed it in the 1960s, their arguments did not evoke strong responses. After reform and opening-up, it has gradually become a debatable issue.

As the current political economy falls within the scope of Marxist economics, the object of study of Capital by Marx is the object of study of political economy. Although Capital (Volume I) has been punished for more than 150 years and Marxist political economy has been studied in China as a discipline and a course for nearly 70 years, the object of study remains a "difficult problem."

From a practical point of view, this "difficult problem" derived from the shift from the socialist planned economy to the socialist market economy. Some scholars believed that the object of study of political economy should be changed accordingly and that the foundation should be found in the debatable arguments of Karl Marx and Friedrich Engels. Of course, some scholars deliberately criticized the so-called "ownership worship" (Wu, 2013) or converted the object of study of Marxist political economy into the object of study of neoclassical economics - "resource allocation" - by studying "productive forces." In theory, controversy originated from a statement in the preface to the first edition of Capital (Volume I), "In this work, I have to examine the capitalist mode of production and the conditions of production and exchange corresponding to that mode." (Marx, 2009a, p. 8) In terms of form, the statement contains three points as follows: (1) the capitalist mode of production; (2) the relations of production corresponding to the capitalist mode of production and (3) the exchange relations corresponding to the capitalist mode of production. The divergence of views lies in two aspects. For one thing, which is the object of study of political economy, the mode of production, relations of production, exchange relations or all of them? For another, what is the correct way to understand the relations of production?

We did not intend to conduct a comprehensive analysis of the above issues but focus the study on understanding the issue of relations of production. Relations of production are closely related to the mode of production and exchange relations. If relations of production are clarified, then the other two categories will be elucidated. More importantly, even when the consensus was gained or among the scholars who have reached a consensus, the understanding of relations of production has never been unanimous. Therefore, it is of significance to clarify relations of production.

\section{The "difficult problem" of the object of study of political economy}

The "difficult problem" of the object of study of political economy originates from the statement in the preface to the first German edition of Capital (Volume I) by Marx, "In this work, I have to examine the capitalist mode of production and the conditions of production and exchange corresponding to that mode." (Marx, 2009a, p. 8) As to this statement, on the one hand, the object of study of political economy is interpreted as the mode of production (Hu, 2015; Yu and Wang, 2001); on the other hand, it is interpreted as the relations of production. They are predominant views. However, divergence arises regarding what relations of production mean. 


\subsection{The relationship between mode of production and relations of production}

There are three kinds of interpretations of the mode of production (Compilation Group of Marxist Theory Research and Construction Engineering Key Textbook, 2012) as follows: (1) it is the relations of production in the broad sense; (2) it refers to the mode of production or the mode of labor, i.e. the use in the sense of productive forces and (3) it denotes socio-economic formation.

Apart from the second interpretation, the first interpretation does not seem contradictory with the predominant view that the object of study of political economy is relations of production because the mode of production is relations of production. Thus, both the mode of production and relations of production refer to relations of production. The third interpretation also resolves the contradiction that the mode of production is inconsistent with relations of production. First, the mode of production is not equal to the capitalist mode of production. The former is a general concept, while the latter is a specific concept - one of many modes of production. Marx studied capitalism only and the other social formations were not included. Therefore, if the relations of production and the exchange relations discussed by Marx refer to the relations of production in the broad sense, the object of study of Capital by Marx shall be the capitalist relations of production in the broad sense.

Some researchers interpreted the mode of production as relations of production, more specifically, as the relations of production in the broad sense, including production, exchange, distribution and consumption, or as the totality of relations of production, social relations of production and economic relations proposed by Marx, rather than the relations of production in the narrow sense arising within the field of production and in parallel with exchange relations and distribution relations $(\mathrm{Wu}, 2013)$. It resolves the contradiction between the mode of production and relations of production but a question is still there. That is, do the relations of production in the broad sense refer to the four sections - production, exchange, distribution and consumption - as an organic whole or only two sections - the production and exchange? After all, the "relations of production" in "the relations of production and exchange relations" corresponding to the capitalist mode of production should be the relations of "production" in the direct production process of material goods, which is the relations of production in the narrow sense excluding "exchange." On the contrary, production relations that include "exchange" become the "relations of production in the broad sense." However, the "relations of production in the broad sense" are defined as an organic whole consisting of the four sections - production, exchange, distribution and consumption. The former interpretation leaves out distribution and consumption. If among the four sections, "production" is the decisive one and "consumption" is the terminal but not the object of study of political economy, why exchange relations are brought up rather than distribution relations?

The theory of the socio-economic formation of the mode of production contains a better understanding of the mode of production in logic, which is also underpinned by the other works by Marx. Afterward, Marx amended the concept of mode of production in the French edition of Capital (Volume I) to avoid confusion. It indicates that Marx meant the object of study of Capital was the relations of production rather than the mode of production that contain productive forces (Hu, 1997). However, the problem - which is the relations of production in the broad sense: the "relations of production and exchange relations" or the four sections as an organic whole - "production, exchange, distribution and consumption" remains to be solved.

\subsection{About the problem of "relations of production"}

According to the analysis abovementioned, the relationship between mode of production and relations of production comes down to the "difficult problem" of "relations of production."

2.2.1 Two different "relations of production in the narrow sense". There are two different interpretations of relations of production in the narrow sense.
Marx's object of study on political economy

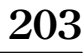


CPE

4,2
(1) The interpretation of the relations of production in the narrow sense in the traditional textbooks includes three aspects: the owner of capital goods, i.e. the ownership of the means of production; the workers' position in the production process and the distribution forms of products. According to Baidu Baike, relations of production in the narrow sense are interpreted as people's relationship in the production process, including the ownership and non-ownership of the means of production, the relations between individuals and the relations of product distribution. Above all, the ownership of the means of production is fundamental and decisive. The two definitions are almost the same. Given the three aspects mentioned above, the ownership of the means of production and the workers' position fall into the production in the four sections. The relations of product distribution belong to the distribution in the four sections. In this case, the "relations of production in the narrow sense" refer to "production and distribution" in the four sections. It is contradictory with the interpretation of "production" in the four sections as the "relations of production in the narrow sense." If it is defined as the relations of production in the broad sense, "the exchange and consumption" are excluded, contradicting Marx's statement on "the relations of production and exchange relations."

(2) The production in "the four sections" belongs to "the relations of production in the narrow sense," which is contradictory to the statement of the first point aforementioned.

2.2.2 Two different "relations of production in the broad sense". There are two different interpretations of "relations of production in the broad sense" as follows:

(1) Relations of production in the broad sense mean the relations formed during reproduction, i.e. the system of relations of production including many relations, such as production, distribution, exchange and consumption. It is an organic whole determined by "production" and constituted by the four sections.

(2) It refers to the "relations of production and exchange relations" discussed by Marx in the preface of Capital. As the four collocated sections of the relations of production in the broad sense form a whole, even if it is believed that the "production" in the narrow sense decides the other relations, the distribution and consumption relations are excluded.

\section{Resolving the "difficult problem"}

In order to solve the "difficult problem" of the object of study of political economy, one must be on board with Marx's statement in Capital, i.e. the object of study of political economy is "the capitalist mode of production and the conditions of production and exchange corresponding to that mode." In this way, the difficult problem changed into how to understand Marx's statement correctly. The various "objects of study of political economy" that rose within the theoretical cycle are mostly different interpretations of this statement by Marx.

\subsection{How should Marx's statement be understood?}

Marx's statement seemed to denote that the object of study of Marxist economics was the mode of production rather than relations of production. However, that is not the case if we analyze it carefully.

First, the mode of production is not the capitalist mode of production. The former is a general concept, while the latter is a specific concept and one of the many modes of 
production. Marx only focused on the capitalist mode of production, excluding the modes of production of the other social formations. The statement in the preface by Marx contains two aspects. On the one hand, only the capitalist mode of production was studied. In other words, Marx only focused on the capitalist economy without the other social formations. Therefore, Marxist economics is "the political economy in the narrow sense" rather than "the political economy in the broad sense." On the other hand, within the capitalist socio-economic formation, the object of study is the corresponding relations of production and exchange relations.

Second, the mode of production is the unity of productive forces and relations of production. If the object of study is the mode of production that involves the relations of production, why are the relations of production and exchange relations mentioned? The point of view that the object of study is the mode of production and relations of production is illogical. Apparently, interpreting it as the relations of production in the capitalist mode of production is logical.

Finally, the mode of production contains three kinds of relationships: the relationship between people, the relationship between people and objects and the relationship between objects. The relationship between people and objects is the materialized form of the relationship between people, while the relationship between people is the essence of the relations between people and objects. Therefore, the three relationships are essentially two relationships: the relationship between people and between objects. The relations between objects belong to the category of natural science research, while the relations between people fall into the category of social science research. Economic activity is a special and yet primary human social activity. Therefore, economics belongs to social science. The productive forces in the mode of production belong to the relationship between objects, which are part of technology and a branch of natural science. From the perspective of commodity property, the "aggregation" of productive forces is pertinent to the use value of commodities but not the value of commodities. The use value provides materials for commodity science (Marx, 2009b, p. 48). Yet, commodity science belongs to natural science but not economics.

Thus, it is fair enough to say that the object of study of political economy is the capitalist relations of production. However, as mentioned above, the relations of production are divided into the ones in the broad sense and the ones in the narrow sense. In addition, there are two interpretations of the relations of production in the broad sense and the ones in the narrow sense, respectively. So which relations of production are the object of study of political economy?

\subsection{The key to solving "the difficult problem" lies in the structure of Capital}

The answer cannot be found directly in Marx's statements. Nevertheless, this problem can be analyzed with Capital as the sample. The paradigm or classic of Marxist political economy is undoubtedly Capital. Therefore, it is necessary to analyze the object of study of Capital. The existing essays that illustrate the object of study of political economy mostly make textual criticisms and explanations on the preface to the first edition of Capital and the preface to $A$ Contribution to the Critique of Political Economy by Marx. Some scholars also studied the other articles by Marx, but they only focused on textual criticisms. Few scholars studied the object of study of political economy based on the paradigm of Marxist political economy or sought to understand Marx's statement on the object of study of Capital through the paradigm. We tried to crack "the difficult problem" of the object of study of political economy from this angle.

The three volumes of Capital are undoubtedly about the capitalist relations of production. Why did Marx argue that the object of study is "relations of production and exchange relations"? The relations of production mentioned herein are obviously the relations of
Marx's object of study on political economy 
CPE

4,2

206

production in the narrow sense with "the exchange relations," which can be interpreted as "the relations of production in the broad sense." However, the two "relations of production in the narrow sense," the two "relations of production in the broad sense" and "their contradictory issues" must be clarified.

In terms of form, the three volumes of Capital focus on the process of capital production, the circulation process of capital and the process of capitalist production as a whole, respectively, or on the production, circulation and distribution of capitalism. The so-called four sections of the relations of production are not collocated but a stratified organic whole. Likewise, the three volumes of Capital are not collocated but also a stratified organic whole. Specifically, the three volumes as a whole focus on capitalist relations of production. Nevertheless, the second layer of the three volumes is dichotomous. That is, the whole of Capital divides into two segments, and the second segment also divides into two. As a result, the whole consists of three layers that correspond to the first, second and third volume of Capital and is illustrated as follows :

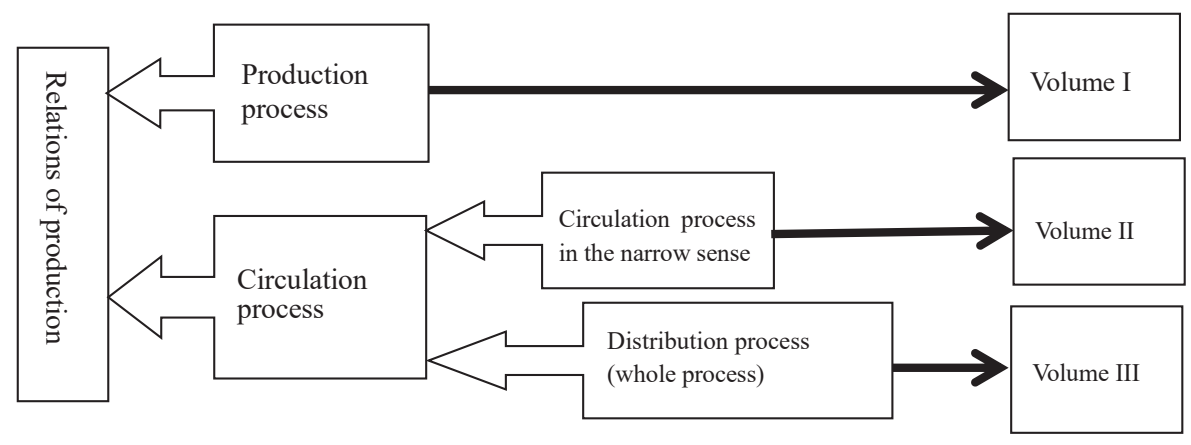

The above diagram suggests that the object of study on political economy is the capitalist relations of production. The relations of production are defined in the broad sense, including "the relations of production in the narrow sense" and "the exchange relations" (circulation represents exchange). Considering the statement in the preface to the first edition of Capital by Marx, the significance of studying "the relations of production and exchange relations" reveals itself.

What is the objective ground to divide the structure of Capital in this way?

There are two grounds. For one thing, the foundation of Marx's method of study is dialectical materialism and historical materialism, i.e. the use of contradiction in his analysis. From a dialectical materialist point of view, any category should be viewed as an organic whole with contradictions. In Capital, almost all the categories are constructed like this. For example, the two factors of the commodity - use value and value - are a contradiction; money is not only "the special commodity" but also "the representation of value," which are a contradiction; capital is not only "the special type of currency" but also "valorizing value"; the organic composition of capital constitutes the technical composition of capital and value composition of capital. These are all dichotomous "“contradictions." The dichotomy of the use of contradiction is also one of the fundamental analysis methods used in Capital. The basic procedure of this method is to take the whole as the highest layer and divide the whole into two-halves. Then, one of the halves divides into two, which forms the third layer. The structure of the three volumes of Capital is arranged in this way. "The relations of production," as a whole, divide into two, which break up into "the production 
process (the relations of production in the narrow sense)" and "the circulation process (exchange relations)." The exchange relations divide into "exchange (circulation) relations" and "distribution relations" in the narrow sense. However, as production, exchange and distribution are an integrated whole, the relations between them cannot be comprehended separately. Regarding this point, Marx made it clear in the preface to A Contribution to the Critique of Political Economy. For another, Marx wrote in the preface to the first edition of Capital (Volume I), "The second volume of this book will treat of the process of the circulation of capital (Book II.), and of the varied forms assumed by capital in the course of its development (Book III), the third and last volume (Book IV), the history of the theory." (Marx, 2009a, p. 13) "The third volume" mentioned herein refers to Theories of Surplus Value, which does not fall into the commonly known category of Capital. In fact, the three volumes of Capital should be called "three books." The "three books" of Capital divide into "two volumes." The first volume is Book I, while the second volume consists of Book II and Book III. Marx dichotomized Capital twice. Amidst the first dichotomization, Capital is divided into Volume I and Volume II; after the second dichotomization, Volume II is divided into Book II and Book III, i.e. the current Volume II and Volume III.

\subsection{How to comprehend "the four-section theory" of relations of production?}

According to the above analysis, the object of study on political economy is neither mode of production nor productive forces but the capitalist relations of production, i.e. "the relations of production in the broad sense" consisting of production, exchange and distribution. They also mean the relations of production in the narrow sense and "the exchange relations in the broad sense" that include exchange and distribution.

Another problem also arises here, i.e. how should "the relations of production in the broad sense" of the four sections - "production, exchange, distribution and consumption" - be viewed? As Marx discussed in detailed the interrelations of "production, exchange, distribution and consumption" in the preface to A Contribution to the Critique of Political Economy, "the four-section theory" is taken as "the relations of production in the broad sense" of the object of study on political economy in most of the textbooks on the political economy. Actually, this opinion is worthy of discussion. Marx indicated that consumption is not within the category of economics. Yet, "the four-section theory" was not put forward by Marx but by James Mill, a classical economist. Marx only discussed the relations of the four sections of the relations of production and clearly stated that "consumption" does not belong to economics when criticizing "the four-section theory" of classical economics.

\section{The object of study of socialist political economy with Chinese characteristics} Discussing the object of study of political economy is not only to solve a "difficult problem" but also to research the object of study of socialist political economy with Chinese characteristics. "Socialist political economy with Chinese characteristics" and "political economy" are two distinctive theories. The former studies the socialist mode of production with Chinese characteristics and the latter studies "the capitalist mode of production." Then, is the object of study of the former utterly different from that of the latter?

Our answer is that there are similarities and differences. On the one hand, the reason why they are rendered the same is that socialist political economy with Chinese characteristics and the political economy both belong to the category of Marxist economics, which should have the same paradigm, method of study and object of study. That is, their objects of study are both supposed to be "the relations of production in the broad sense." The specific object and method of study decide the nature of a theory. Only by adhering to the method of study and the object of study of Marxist political economy can the Marxist nature of the socialist
Marx's object of study on political economy 
CPE

4,2

208

political economy with Chinese characteristics be ensured. Undoubtedly, the socialist political economy with Chinese characteristics is Marxist. If the object of study is replaced as "resource allocation" of neoclassical economics, i.e. the productive forces are studied, then the nature of the theory is sure to be changed. In other words, this so-called socialist political economy with Chinese characteristics is no longer Marxist economics (Yang, 2017). On the other hand, they are viewed as different because their "relations of production" and the concrete contents of relations of production are both distinctive. The former is the socialist relations of production with Chinese characteristics, while the latter is the capitalist relations of production. Some scholars believed that the traditional Marxist political economy, which focused on relations of production with negligence of productive forces, was defective. As the current task of socialism with Chinese characteristics is to liberate and develop productive forces, the socialist political economy with Chinese characteristics should be studied with the universal paradigm and method of study of modern economics and the focus on studying resource allocation, i.e. studying productive forces (Hong, 2017). Some researchers also put forward another question: Is "socialist political economy with Chinese characteristics" the political economy of socialism with Chinese characteristics or the socialist political economy with Chinese characteristics (Zhang, 2017)? Also, we believe there is one more question: Does the socialist political economy with Chinese characteristics deal with the socialist mode of production since the founding of New China (including the planned economic mode of production before the reform and opening up and the market economic mode of production after reform and opening up) or only the socialist market economy after reform and opening up?

These questions are discussed in the following three points.

\subsection{Should socialist political economy with Chinese characteristics focus on studying productive forces?}

The reason for this argument was that the traditional political economy did not attach importance to studying productive forces. According to Marx, productive forces and relations of production constitute a whole and a certain mode of production. As productive forces play an ultimate decisive role in the mode of production, relations of production have adverse effects on the development of productive forces. After a certain mode of production is established, the development of productions forces of a certain society is restrained by the relations of production, and the development of productive forces serves specific relations of production. The aim of studying relations of production is not only to reveal the specific social-economic development law but also to identify what kind of relations of production can facilitate the development of productive forces and what kind of relations of production hinder the development of productive forces. In Capital, by studying the capitalist relations of production, Marx revealed how the development of capitalist productive forces is intrinsically facilitated and restrained. Under the capitalist mode of production, as capitalists seek surplus value, especially extra surplus-value, they enhance the labor intensity, improve the production technology and management and constantly increase the labor productivity. Some capitalists increase the social labor productivity and facilitate the advance of scientific technology via social competition. This mechanism does prove how productive forces grow and develop. Marx also studied how the corporate internal division of labor increased labor productivity and how the corporate internal division of labor was transferred into the social division of labor and increased social labor productivity. Under the capitalist mode of production, the way that capitalists adopt to gain the surplus value and extra surplus value not only facilitates the improvement of labor productivity but also leads to the increase of the organic composition of capital, the reduction of the general profit rate, the damage to the conditions of extended reproduction and, eventually, the periodical 
economic crisis. Therefore, it is groundless to say that traditional political economy neglects productive forces.

Suppose the object of study is not the capitalist relations of production but the development of productive forces in the abstract sense. In that case, the dialectical process of the development of the capitalist productive forces cannot be explained. If "the resource allocation," i.e. productive forces, is abstractly studied with a disregard for the specific relations of production, it would fail to explain (1) whether the productive forces are developed to the maximum extent or get hindered and (2) what the development of productive forces is for. The capitalist productive forces develop for capital, and the productive forces become a tool for capital gain. Beyond these limits, no matter how advanced productive forces are, it will not boost the development of capital. On the contrary, socialist productive forces develop to meet the people's expectation for a well-off life to the greatest extent. If the relations of production at a certain stage of socialism hinder the goal, then the relations of production should be adjusted.

Thus, the object of study of the political economy cannot be resource allocation, i.e. abstract study on productive forces or study on relations of production collocating with productive forces. In the latter case, relations of production and productive forces are separated rather than viewed as an organic whole.

\subsection{Should the study of socialist political economy with Chinese characteristics include "planned economy"?}

The socialist mode of production with Chinese characteristics is a part of the study of socialist political economy with Chinese characteristics, and the development of socialism with Chinese characteristics has included two stages: the socialist planned economy period and the socialist market economy period. It remains unexplored whether the scope of the study of socialist political economy with Chinese characteristics should include these two periods.

On July 8, 2016, CPC (the Communist Party of China) General Secretary Xi Jinping pointed out clearly at a symposium on the economic situation, "To uphold and develop the socialist political economy with Chinese characteristics, we must take the Marxist political economy as the guiding force, summarize and refine the nation's great practical experience of reform and opening up and socialist modernization, and learn from the essence of the western economics." (Xi, 2016, p. 1), In his statement, he indicated the socialist political economy with Chinese characteristics is Marxist, and the object of study includes socialist planned economy and socialist market economy. The implementation of the reform and opening-up policy is mainly within the socialist market economy period, while the process of socialist modernization includes the planned economy period. During the planned economy period in China, not only the basic socialist economic system was established, but also "the four modernizations" were specified and carried out. A complete industrial economic system was basically set up, which created the material conditions for reform and opening up and the construction of the socialist market economy.

According to the Central Government's spirit of "not making the two periods mutually contradictory," the two stages belong to socialism with Chinese characteristics, which adheres to the principle of Marxist historical materialism. Socialist-planned economy and socialist-market economy are both determined by the specific historical periods of China, which are both inevitable and reasonable. The former is the basis of the latter, while the latter is the consequent progress of the former. Therefore, the study of socialist political economy with Chinese characteristics should cover the two periods. Otherwise, the basis of the socialist market economy construction (i.e. the primitive accumulation of state capital) and its success cannot be explained. Neither can it be logically elucidated that the two stages both belong to the socialist relations of production. However, comparatively, the former period lasted relatively shorter and the latter period relatively longer. The socialist-market economy has
Marx's object of study on political economy

209 
CPE

4,2

existed for more than 40 years since reform and opening up and will last for quite a long time. On the contrary, the planned economy lasted less than 30 years. Hence, the study on socialistpolitical economy with Chinese characteristics covers two periods, with a bias toward the socialist-market economy period, and the research should focus on how socialist-market economy works.

4.3 What specific relations of production should the object of study of socialist political economy with Chinese characteristics contain?

The specific object of study should be determined in combination with the method of study. In fact, the determination of the object of study itself can be viewed as one of the methods of study in the broad sense. For example, the specific scope of the object of study will not be clarified until the logical starting point has been identified. The logical starting point is the starting point in history, which involves the above-mentioned question - "to start with the socialist planned economy or the social market economy." The answer is to start with the socialist-planned economy. In addition, socialist-political economy with Chinese characteristics must follow Marx's method of scientific abstraction, i.e. studying issues from concrete to abstract and narrating issues from abstract to concrete. In Capital, Marx started from the most abstract concept, commodity (the logical starting point), built the structure around capital and studied the origin, production, circulation and distribution of capital. In his view, historically, capital movements happen from individual to social levels and domestic to international levels. Karl Marx's "Six-book Plan" (Capital, Landed Property, Wage-labor, the State, Foreign Trade and World Market) indicates that the content of Capital mainly contains the former three books, dealing with the movement of capital within a country. The system of socialism with Chinese characteristics was established in the context of internationalization. Therefore, given crossborder capital flows, the origin of the "state capital" [2], the laws of motion of production, circulation and distribution and the relations of foreign trade and world market with socialism with Chinese characteristics should be studied based on Marx's train of thought. Some of the main points are listed as follows:

First, illustrate the reason for the inevitable failure of capitalism in the large backward semi-feudal and semi-colonial countries and the reason and course of the definite victory of socialism in the era of globalization of capital flows under the siege of capitalism.

Second, expound "the primitive accumulation" of socialism with Chinese characteristics, which is different from the primitive accumulation of capitalism. The primitive accumulation of the state capital can be used to illustrate the necessity of implementing the planned economy with public ownership at the initial stage of socialism with Chinese characteristics and the corresponding circulation and distribution systems.

Third, illustrate how private capital turns into "state capital" under the establishment of the socialist relations of production. This kind of state capital entails a "dual nature" as follows: within a socialist country, it refers to the form of motion of the publicly owned means of production, and in the global context, it engages in the competition in international capital markets and contains the property of capital.

Fourth, after the completion of primitive accumulation of socialism with Chinese characteristics; in other words, after the basic establishment of a complete industrial framework, China has been fundamentally positioned for competing against the international capital of capitalism and experienced the transition from the socialist-planned economy to the market economy. Since then, China has adopted the basic economic system with public ownership playing a dominant role and diverse forms of ownership developing side by side, with the coexistence of private capital and public capital domestically. Since the emergence of private capital domestically, public capital and private capital face the same market competition. Against the backdrop of the socialist market economy with Chinese 
characteristics, public capital and private capital constitute the "state capital," which competes against the international capital, thus giving the state capital a dual nature both domestically and internationally: "affinity to the people" and the profitability of capital. The profitability of capital should be a means of the state capital's affinity to the people, serving the system of socialism with Chinese characteristics.

Fifth, the organization of production, management manner, circulation pattern, distribution system, growth pattern, accumulation system and development strategy are under the socialist-market economy with Chinese characteristics.

Sixthly, in the context of socialism with Chinese characteristics, the relations of government to market, the public ownership to private ownership, China's economy to global economy, income gap to common prosperity, nationalism to globalism, etc.

\section{Conclusion}

The object and method of study need to be identified in advance for constructing the socialist political economy with Chinese characteristics, which determine the nature of the theory. At the abstract level, the object of study of socialist-political economy with Chinese characteristics is the same as that of political economy. Therefore, clarifying the object of study of political economy becomes the pre-condition for identifying the object of study of socialist-political economy with Chinese characteristics.

As there are different interpretations of the statement about the object of study of Capital in the preface to the first edition of Capital (Volume I), there has been a difference of opinion on the object of study of political economy, and the jury is still out, leaving it one of the "difficult problems" to consider when studying Marxist economics. Based on the analysis of the logic of the original texts, we attempted to give a new interpretation of the object of the study of political economy by analyzing the structure of Capital. We believe that the object of study of political economy is "the relations of production in the broad sense" in the economic form of capitalization. The relations of production in the broad sense can be divided into production, circulation and distribution regarding the so-called "four-section theory" of relations of production. The reason why Karl Marx said that the object of study of political economy was "the conditions of production and exchange" regarding the capitalist mode of production was that according to the method of contradiction analysis, the relations of production in the broad sense could be first divided into relations of production in the narrow sense and the exchange relations in the broad sense; then, the exchange relations in the broad sense could be dichotomized into exchange relations in the narrow sense and distribution relations, which corresponds to Volume I, II and III of Capital, respectively. And such a division has been testified by Marx with the statement in the preface to the first edition of Capital (Volume I).

Consumption in "the four sections" is not covered by political economy. "The four-section theory" does not belong to Marxist economics but classical economics. Marx criticized classical economists' mistake of collocating the four sections and analyzing them separately and analyzed their dialectical relations correctly in the preface of $A$ Contribution to the Critique of Political Economy. Most political economy textbooks viewed the four sections production, circulation, distribution and consumption - as "relations of production in the broad sense" proposed by Marx, which was not appropriate.

Socialist-political economy with Chinese characteristics is the latest achievement of Marxist-political economy in China, which falls into the category of Marxist-political economy. Of course, its object of study should be "the relations of production in the broad sense" of the socialist mode of production with Chinese characteristics. However, as socialism with Chinese characteristics and capitalism are entirely distinctive social formations, the specific contents of the relations of production are different. The specific contents should be studied on the premise of insisting the object of study of socialist political economy with
Marx's object of study on political economy 
CPE 4,2

Chinese characteristics is "the relations of production in the broad sense." In this article, we have made some tentative guidance on the detailed contents.

\section{Notes}

1. The article "Innovating the Research Object of Political Economy" by Wei Xinghua published on People's Daily, Page 7, on December 21, 2016 was not focused on the object of study in socialist political economy with Chinese characteristics.

2. State capital" is a concept created in this article, referring to the monetary form of the "public means of production" and the operation pattern of its capitalization in the socialist economy with Chinese characteristics, as contrast to "private capital." This concept is different from the "social capital" (socialized capital) in the capitalist economy, such as share capital. The social capital is private, while state capital is public owned. Unlike the current concept of "state-owned capital," "state capital" includes the monetary form of the means of production and its operation pattern in the era of planned economy.

\section{References}

Compilation Group of Marxist Theory Research and Construction Engineering Key Textbook (2012), Zibenlun Daodu [Introduction to Das Kapital], Higher Education Press and People's Publishing House, Beijing.

Hong, Y.M. (2017), "Zhanzai zhongguoren de lichang shang, yong xiandai fangfa yanjiu wenti, yong guoji yuyan jiangshu zhongguo gushi [Stand in the Position of Chinese, Research Chinese Issues with Modern Methods, Tell Chinese Stories in International Languages]", Jingii Yanjiu [Economic Research Journal], Vol. 52 No. 5, pp. 19-21.

Hu, J. (1997), "Dui zibenlun yanjiu duixiang de zairenshi [Re-thinking of the Research Object of Das Kapital]", Jingjixuejia [Economist], Vol. 9 No. 2, pp. 14-19.

Hu, S.Z. (2015), "Dui zhengzhi jingjixue ruogan fanchou chuantong renshi de zhiyi [Questioning the Traditional Understanding of Several Categories of Political Economy]", Dangdai Jingii Yanjiu [Contemporary Economic Research, Vol. 26 No. 6, pp. 5-12.

Marx, K. (2009a), "Preface", in Central Compilation and Translation Bureau (Ed.), Makesi Engesi Wenii: Diwujuan [Marx and Engels Collected Works: Volume V], (Chinese translation edition translated by Central Compilation and Translation Bureau), People's Publishing House, Beijing, pp. 8-13.

Marx, K. (2009b), “Commodities”, in Central Compilation and Translation Bureau (Ed.), Makesi Engesi Wenji: Diwujuan [Marx and Engels Collected Works: Volume V], (Chinese translation edition translated by Central Compilation and Translation Bureau), People's Publishing House, Beijing, p. 48.

Wei, X.H. (2016), "Chuangxin zhengzhi jingjixue yanjiu duixiang [innovating the research object of political economy]", People's Daily, December 21, p. 7.

Wu, X.G. (2013), "Lun zuowei zhengzhi jingjixue yanjiu duixiang de shengchan fangshi fanchou [On the Category of Production Mode as the Object of Study of Political Economy]", Dangdai Jingji Yanjiu [Contemporary Economic Research, Vol. 24 No. 3, pp. 1-10.

Xi, J.P. (2016), "Xi Jinping zhuchi zhaokai jingji xingshi zhuanjia zuotanhui [Xi Jinping presided over an expert symposium on economic situation]", People's Daily, July 9, p. 1.

Yang, J.G. (2017), "Zhongguo tese shehui zhuyi zhengzhi jingjixue jige fangfalun wenti [Several Methodological Issues in Socialist Political Economy with Chinese Characteristics]", Wuhan Keji Daxue Xuebao: Shehui Kexue Ban [Journal of Wuhan University of Science and Technology: Social Science Edition, Vol. 19 No. 6, pp. 602-608.

$\mathrm{Yu}$, J.F. and Wang, S.L. (2001), "Cong zibenlun jiegou chongxin renshi zhengzhi jingjixue yanjiu duixiang [Re-thinking on the Research Object of Political Economics from the Structure of Das Kapital]", Dangdai Jingji Yanjiu [Contemporary Economic Research], Vol. 12 No. 3, pp. 52-56. 
Zhang, Y. (2017), "Nuli tansuo he wanshan zhongguo tese shehui zhuyi zhengzhi jingjixue lilun tixi [Researching and Completing the Theory of Socialist Political Economy with Chinese Characteristics]", Zhengzhi Jingjixue Pinglun [China Review of Political Economy], Vol. 8 No. 2, pp. 3-12.

Marx's object of study on political economy

\section{Corresponding author}

Jiguo Yang can be contacted at: xmyjg4486@189.cn

For instructions on how to order reprints of this article, please visit our website: www.emeraldgrouppublishing.com/licensing/reprints.htm Or contact us for further details: permissions@emeraldinsight.com 